$\checkmark$ of the department of Essone.

In his

statement, Allègre says that "to

preserve the possibility of realizing other, more

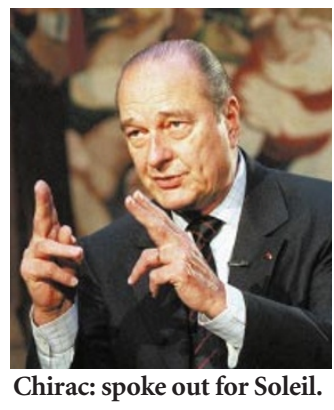

urgent,

projects, we could have simply decided not to finance the synchrotron project, seen as too expensive and not urgent. We did not do that. The strategy adopted was to preserve the interests of the French scientific community, in particular the users of synchrotron radiation, in searching for a European solution.

"Are we in the future going to be lacking synchrotron time? Nothing indicates that. Of course, certain administrators and some users of these machines say so, and without doubt believe it, but experience teaches us that in this domain it is difficult to plan ahead."

To boost research labs, emerging disciplines and the recruitment of young scientists, Allègre says he has decided to rebalance the budget by decreasing the funds spent on large facilities. To accomplish such a reduction, Allègre says his aim is to make any new, large facilities European.

The minister adds that he chose Diamond, the planned 3-GeV machine, because FF1.1 billion of the FF1.8 billion (US $\$ 286$ million) needed will be paid by the Wellcome Trust, whereas the French and British governments will each pay FF350 million.

Scientists at LURE challenge some of his figures, arguing, for example, that Allègre underestimates the X-ray needs of French researchers. In contrast to Allègre's statement that French machines are not "saturated", they argue that LURE accepts only 65 per cent of requests for beam-time.

The international synchrotron community has supported the protests, backing the claims of French scientists that they were largely ignored in the decision-making process. Among those behind LURE's cause are the British Nobel Prize winner Max Perutz and the directors of numerous European synchrotron facilities.

But France will only build Soleil if opposition emerges within Allègre's ruling Socialist party. Some members of the party have been critical, but prime minister Lionel Jospin has yet to make a statement on the matter. Heather McCabe

\title{
cDNA sequence databank will safeguard research access
}

\section{Phoenix, Arizona}

The US National Institutes of Health (NIH) is about to announce details of the creation of a repository for full-length human complementary DNAs (cDNAs), which will provide a source of both genetic sequences and clones for any researcher who requires them.

The Mammalian Gene Collection, which will eventually also include full-length mouse and rat cDNAs, is designed to bring together molecular data stored by individual researchers. The collection, which federal officials say has been allocated total funding of $\$ 10$ million, hopes to have its Internet website functioning next month.

Organizing efforts are being led by the collection's co-directors, Robert Strausberg, assistant to the director of the National Cancer Institute, and Elise Feingold of the National Human Genome Research Institute. Officials say that support for the collection is coming from 16 of the NIH's institutions and the National Library of Medicine.

"We are building this as a resource where anyone can get clones and all information will be available to anyone," said Strausberg. The public storage and availability of such data is being undertaken in part to combat some restrictive corporate efforts to withhold results for proprietary reasons. A full description of the Mammalian Gene Collection will appear in an article in Science.

The principal goal of the collection is to expand genetic storage from expressed sequence tags (ESTs) to full-length cDNA, said Strausberg, who revealed the plans for the repository last week at a meeting on microarrays sponsored by Nature Genetics.

More than a million ESTs are stored in GenBank, a repository operated by the National Center for Biotechnology Information. Some ESTs correspond with known genes, whereas others represent partially sequenced novel genes. Providing molecular biologists with a full cloned sequence will give researchers an expanded canvas of genetic material to work with, while ensuring wide access to the crucial information.

The ever-growing need for more molecular depth was evident at the meeting in Phoenix, where about 400 molecular biologists heard presentations on new techniques and discoveries. With microarray technology, researchers can profile the expression pattern of tens of thousands of genes in a single experiment by arraying DNA targets on glass slides or membranes and probing them with fluorescent or radioactively labelled cDNA.

As well as using microarray technology for fundamental discoveries, researchers are broadening applications into disease diagnosis and plant biology. The technology is being used to try to determine the molecular cause of diseases, helping to define new classifications of diseases and redirect treatments for some malignancies. Rex Dalton

\section{Fur flies over rare-species panel}

\section{Montreal}

Canadian biologists and environmental groups are angry at what they claim are continued efforts by provincial and federal governments to politicize the process by which species are added to the endangered list. In particular, they are worried at moves to give representatives from private corporations direct involvement in the process.

Earlier this year, more than 600 scientists wrote to the prime minister, Jean Chrétien, demanding that the rights to identify and list endangered species be given exclusively to scientists, and that politicians should not be allowed to override such decisions.

Christine Stewart, then Canada's environment minister, responded by adding eight more scientists as voting members to the Committee on the Status of Endangered Wildlife in Canada (COSEWIC), which identifies the species that should be on the list (Nature 398, 9 \& 358; 1999). The govern- ment had previously removed the voting rights of most non-governmental scientist members.

But a draft operating manual for the committee, leaked to The Globe and Mail newspaper in Toronto, shows that, for the first time, members of private corporations would be allowed to sit on the committee.

Committee member Gilles Seutin of McGill University says that many members are concerned that the government is trying to dilute its decisions. And David Schindler of the University of Alberta, who drafted the earlier letter to the prime minister, says there is no place for non-scientists, politicians or industry representatives on COSEWIC. Schindler cites the possibility of a biologist working for a forestry company that might have an interest in not seeing a particular bird placed on the list.

According to the newspaper report, the leaked document also says that COSEWIC 


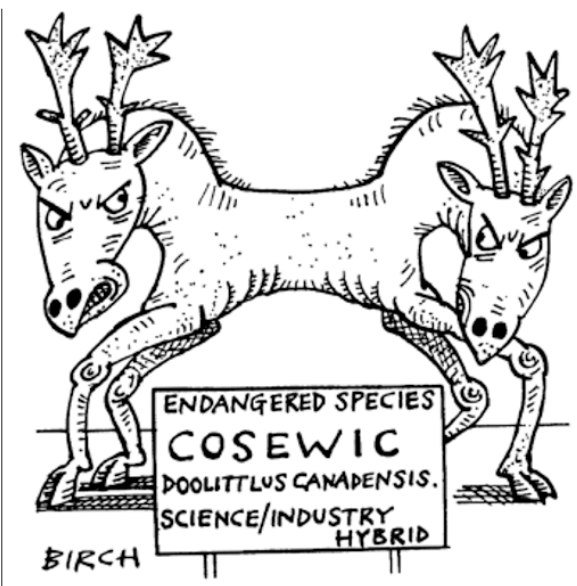

would no longer be able to release its endangered species list independently, but could only do so jointly with federal and provincial wildlife ministers, and the new Canadian Endangered Species Conservation Council.

Sarah Dover, director of the Canadian Endangered Species Campaign for the Canadian Nature Federation, says that, because the council is a political body, "there could be political interference".

But David Brackett, director-general of the federal Canadian Wildlife Service, maintains that adding corporate representatives would not interfere with the committee's independence.

David Spurgeon

\section{Spanish university chiefs blast recruitment system}

\section{Barcelona}

A survey by Spain's Council of Universities has revealed widespread dissatisfaction among university heads with the procedures for faculty appointments (see Nature 396, 709 \& 712; 1998).

The results of the survey were revealed by Jorge Fernández-Díaz, state secretary of education and universities, during a meeting in Santander this month on the future of university government.

The survey polled the Council of Universities, whose members include university vice-chancellors, heads of regional education departments, and 15 other members and presidents of the Social Councils - bodies that supervise university departments about recruitment, funding and the performance of university governing bodies.

University appointment boards have five members, two of whom belong to the recruiting university. Three votes are needed to approve an appointment, and most observers — including government and university officials - agree that it is usually easy to secure the third vote for a favoured local candidate.

Of those surveyed, 84 per cent disagreed that "the system of access to professorial posts is appropriate for an effective selection of research and teaching personnel". Asked about the composition of the evaluation panels, most said that the number of members chosen by lot should be increased.

Fifty-eight per cent said that at least four members should be chosen this way, and seven per cent said all five members should be chosen by lot. Only eight per cent thought the current system should be maintained.

One in five said that there should be an increase in the number of members designated by the university at which the appointment is being made, and 15 per cent said that all members should be designated by the university.

Leonardo Sánchez-Ferrer of the Universidad Complutense de Madrid, who carried out the survey, says that demands for greater autonomy in universities are traditionally louder in nationalistic regions such as Catalonia, which could lead to resistance to change.

Mariano Rajoy, minister of education and culture, told the Santander meeting that "a profound and integral change" is needed in the university reform law. Xavier Bosch

\section{Geographer sues critics of his rock-dating methods}

\section{San Diego}

An Arizona State University (ASU)

geographer under federal investigation for possible scientific misconduct is suing the authors of an article in Science that claimed that the geographer's rock-dating methods were fundamentally flawed.

According to court records, Ronald Dorn contends that the authors "intentionally manipulated, omitted and misrepresented data for the purpose of making it appear [Dorn] engaged in professional misconduct and impropriety". The authors include leading Earth scientists from the University of Arizona and Columbia University.

The article reported that 80 of Dorn's samples of rock varnish contained what appeared to be pieces of coal and charcoallike material (see Science 280, 2132-2135; 1998). Mixing these substances — which have widely differing radiocarbon dates can produce any desired date for a sample.

Dorn's dating method involves scraping varnish off rocks and employing radiocarbon labs to date samples from geological formations and rock art sites.

Some authors of the Science article first reported suspicions about Dorn in 1996 to the Office of the Inspector General of the National Science Foundation (NSF), which funded much of Dorn's research on the questioned samples of rock varnish (see Nature 392, 218-219; 1998).

ASU has completed its investigation of Dorn, according to a university official, and sent its findings to the NSF's inspectors, who will determine whether any misconduct occurred. Neither ASU nor NSF officials would disclose the university's conclusions, nor comment on the probe.

Dorn filed his lawsuit on 25 June, a day before the statute of limitations would have expired for filing a complaint about the Science article. Dorn's attorney, Terry Hall, did not respond to interview requests.

Dorn's lawsuit was filed against Warren Beck, Douglas J. Donahue, A. J. T. Jull and George Burr, of the University of Arizona's NSF-funded Accelerator Mass Spectrometer Laboratory; Wallace S. Broecker of the Lamont Doherty Earth Observatory at Columbia University, which is also a named defendant; and Ekkehart Malotki of Northern Arizona University.

Dorn also sued the wives of the scientists, in an apparent attempt to maximize potential economic recovery and pressure. But the lawsuit does not name Eidgenössische Technische Hochschule, the Swiss institution whose staff contributed to the Science article.

Tommy Thompson, the University of Arizona's attorney for that campus's authors, declined to comment, as did those of the authors contacted by Nature. The authors have denied previous contentions by Dorn that they manipulated results to impugn him. Court records show that Dorn's attorney has not served the authors with the lawsuit, which officially starts the court process before a judge. The attorney must serve the defendants within 120 days from 25 June or risk dismissal of the case.

Dorn is suing for defamation, intentional infliction of emotional distress and interference with prospective economic advantage. In the latest twist in the case, on 21 September Dorn's attorney filed a claim - a prelude to a lawsuit - against the University of Arizona and its authors, alleging that they mislabelled, confused or contaminated 96 rock samples submitted for radiocarbon dating. Dorn is seeking $\$ 482,542$ in damages.
Rex Dalton 